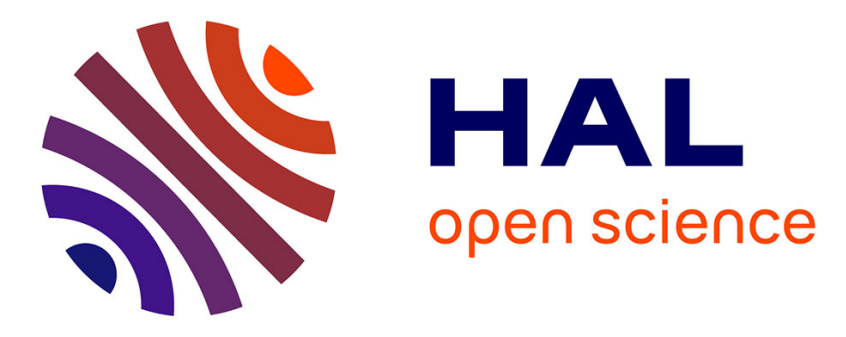

\title{
Higher order schemes in time for the surface quasigeostrophic system under location uncertainty
} Camilla Fiorini, Long Li, Étienne Mémin

\section{To cite this version:}

Camilla Fiorini, Long Li, Étienne Mémin. Higher order schemes in time for the surface quasigeostrophic system under location uncertainty. vEGU 2021, Apr 2021, Vienna / Virtual, Austria. pp.1. hal-03221190

\author{
HAL Id: hal-03221190 \\ https://hal.inria.fr/hal-03221190
}

Submitted on 7 May 2021

HAL is a multi-disciplinary open access archive for the deposit and dissemination of scientific research documents, whether they are published or not. The documents may come from teaching and research institutions in France or abroad, or from public or private research centers.
L'archive ouverte pluridisciplinaire HAL, est destinée au dépôt et à la diffusion de documents scientifiques de niveau recherche, publiés ou non, émanant des établissements d'enseignement et de recherche français ou étrangers, des laboratoires publics ou privés. 


\section{Higher order schemes in time for the surface quasi- geostrophic system under location uncertainty}

Camilla Fiorini ${ }^{*}$, Long $\mathrm{Li}^{1}$, and Étienne Mémin ${ }^{1}$

${ }^{1}$ Inria Rennes - Bretagne Atlantique, France.

In this work we consider the surface quasi-geostrophic (SQG) system under location uncertainty (LU) and propose a Milstein-type scheme for these equations. The LU framework, first introduced in [1], is based on the decomposition of the Lagrangian velocity into two components: a large-scale smooth component and a small-scale stochastic one. This decomposition leads to a stochastic transport operator, and one can, in turn, derive the stochastic LU version of every classical fluiddynamics system.

SQG in particular consists of one partial differential equation, which models the stochastic transport of the buoyancy, and an operator which relies the velocity and the buoyancy.

For this kinds of equations, the Euler-Maruyama scheme converges with weak order 1 and strong order 0.5. Our aim is to develop higher order schemes in time: the first step is to consider Milstein scheme, which improves the strong convergence to the order 1 . To do this, it is necessary to simulate or estimate the Lévy area [2].

We show with some numerical results how the Milstein scheme is able to capture some of the smaller structures of the dynamic even at a poor resolution.

\section{References}

[1] E. Mémin. Fluid flow dynamics under location uncertainty. Geophysical \& Astrophysical Fluid Dynamics, 108.2 (2014): 119-146.

[2] J. Foster, T. Lyons and H. Oberhauser. An optimal polynomial approximation of Brownian motion. SIAM Journal on Numerical Analysis 58.3 (2020): 1393-1421. 